University of South Florida

DIGITAL COMMONS

Digital Commons @ University of

@ UNIVERSITY OF SOUTH FLORIDA

South Florida

$12-2008$

\title{
Si Cycle in the Cariaco Basin, Venezuela: Seasonal Variability in Silicate Availability and the Si:C:N Composition of Sinking Particles
}

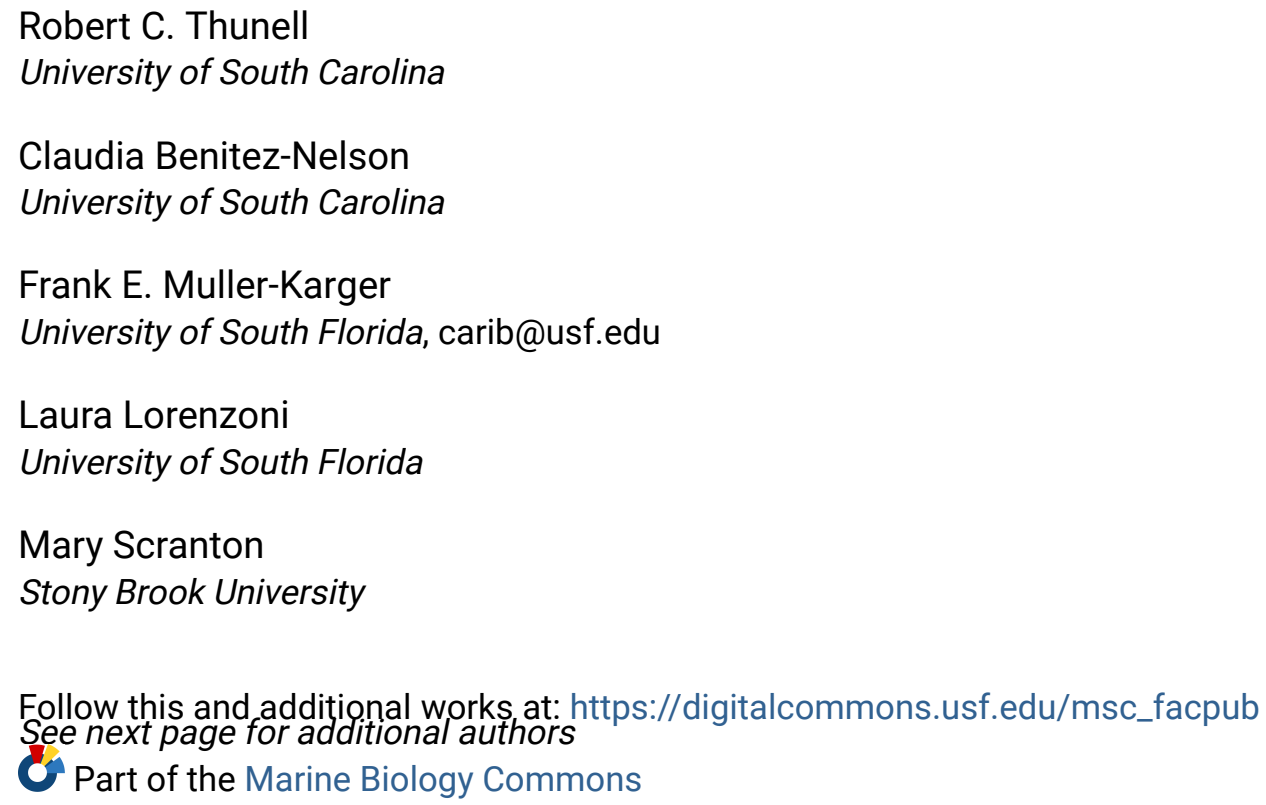

\section{Scholar Commons Citation}

Thunell, Robert C.; Benitez-Nelson, Claudia; Muller-Karger, Frank E.; Lorenzoni, Laura; Scranton, Mary; Varela, Ramon; Astor, Yrene; and Fanning, Kent A., "Si Cycle in the Cariaco Basin, Venezuela: Seasonal Variability in Silicate Availability and the Si:C:N Composition of Sinking Particles" (2008). Marine Science Faculty Publications. 19.

https://digitalcommons.usf.edu/msc_facpub/19

This Article is brought to you for free and open access by the College of Marine Science at Digital Commons @ University of South Florida. It has been accepted for inclusion in Marine Science Faculty Publications by an authorized administrator of Digital Commons @ University of South Florida. For more information, please contact digitalcommons@usf.edu. 


\section{Authors}

Robert C. Thunell, Claudia Benitez-Nelson, Frank E. Muller-Karger, Laura Lorenzoni, Mary Scranton, Ramon Varela, Yrene Astor, and Kent A. Fanning 


\title{
Si cycle in the Cariaco Basin, Venezuela: Seasonal variability in silicate availability and the $\mathrm{Si}: \mathrm{C}: \mathrm{N}$ composition of sinking particles
}

\author{
Robert Thunell, ${ }^{1}$ Claudia Benitez-Nelson, ${ }^{1}$ Frank Muller-Karger, ${ }^{2}$ Laura Lorenzoni, ${ }^{2}$ \\ Kent Fanning, ${ }^{2}$ Mary Scranton, ${ }^{3}$ Ramon Varela, ${ }^{4}$ and Yrene Astor ${ }^{4}$
}

Received 27 August 2007; revised 14 March 2008; accepted 8 July 2008; published 1 October 2008.

[1] A 9-year time series of water column and sediment trap measurements was used to examine silicon cycling within the anoxic Cariaco Basin. The dynamic hydrographic regime within Cariaco Basin results in strong seasonal changes in nutrient availability and the Si:C:N of sinking particles. Upwelling in early winter injects silicic acid $\left(\mathrm{Si}(\mathrm{OH})_{4}^{\bar{\prime}}\right)$ and nitrate $\left(\mathrm{NO}_{3}^{-}\right)$rich waters into the photic zone which stimulates primary production and results in opal fluxes in excess of $4 \mathrm{mmol} \mathrm{Si} \mathrm{m}{ }^{-2} \mathrm{~d}^{-1}$. However, even during upwelling, surface waters tend to be depleted $(<1 \mu \mathrm{M})$ in both $\mathrm{Si}(\mathrm{OH})_{4}^{\overline{ }}$ and $\mathrm{NO}_{3}^{-}$as a result of rapid utilization. In most years, the upper water column during winter and spring is marked by $\mathrm{Si}(\mathrm{OH})_{4}=\mathrm{NO}_{3}^{-}$and $\mathrm{Si}^{*}$ values of less than 1 . This indicates that silicate limitation in Cariaco Basin is most severe during upwelling and may restrict diatom production. Conversely, during the summer and fall when upwelling is reduced, $\mathrm{Si}(\mathrm{OH})_{4}^{=}$ $: \mathrm{NO}_{3}^{-}$ratios in the upper $50 \mathrm{~m}$ of the water column exceed 10, implying that nitrate rather than silicate is acting to limit production during this time of year. On average, sinking particles collected at 150-m depth in the Cariaco Basin have Si:C and Si:N values of 0.17 \pm 0.01 and $1.14 \pm 0.10$, respectively. These ratios increase with depth to $400 \mathrm{~m}$ and then remain relatively constant, suggesting minimal selective removal of elements with remineralization in the anoxic portion of the water column. Similar depth-dependent changes in these ratios are seen in surface sediments from the basin. Seasonally, particulate $\mathrm{Si}: \mathrm{C}$ and $\mathrm{Si}: \mathrm{N}$ are highest during the early part of the year when upwelling is most intense, while both ratios decrease to their lowest values during summer and fall. The observed seasonal variability in these ratios is due to changes in both nutrient utilization by diatoms and the contribution of diatoms to the total phytoplankton. The high ratios during upwelling suggest enhanced export of Si relative to $\mathrm{C}$ and $\mathrm{N}$ during this time of year.

Citation: Thunell, R., C. Benitez-Nelson, F. Muller-Karger, L. Lorenzoni, K. Fanning, M. Scranton, R. Varela, and Y. Astor (2008), Si cycle in the Cariaco Basin, Venezuela: Seasonal variability in silicate availability and the Si:C:N composition of sinking particles, Global Biogeochem. Cycles, 22, GB4001, doi:10.1029/2007GB003096.

\section{Introduction}

[2] Diatoms are one of the most important primary producers in the oceans, possibly accounting for as much as $30-40 \%$ of total primary production [Nelson et al., 1995; Treguer et al., 1995]. As such, diatoms are a major vehicle for carbon export from surface waters, particularly in high latitudes and upwelling regions [Buesseler, 1998]. Thus, the

\footnotetext{
${ }^{1}$ Department of Geological Sciences and Marine Science Program, University of South Carolina, Columbia, South Carolina, USA.

${ }^{2}$ College of Marine Science, University of South Florida, St. Petersburg, Florida, USA.

${ }^{3}$ Marine Sciences Research Center, Stony Brook University, Stony Brook, New York, USA.

${ }^{4}$ Fundacion La Salle de Ciencias Naturales, Estacion de Investigaciones Marinas de Margarita, Isla de Margarita, Venezuela.

Copyright 2008 by the American Geophysical Union. 0886-6236/08/2007GB003096
}

production and cycling of biogenic opal $\left(\mathrm{bSiO}_{2}\right)$ is an important component of the ocean's biological pump [Sarmiento and Gruber, 2006; Ragueneau et al., 2006] and may play a major role in regulating the exchange of $\mathrm{CO}_{2}$ between the ocean and atmosphere on a variety of timescales [Brzezinski et al., 2002; Sarmiento et al., 2004]. Despite this direct linkage between diatoms, primary production, and carbon export from the upper ocean, some workers have argued that there is a decoupling between the silicon ( $\mathrm{Si}$ ) and carbon (C) cycles based on geographic variations in $\mathrm{Si}$ and $\mathrm{C}$ uptake during opal production [Ragueneau et al., 2002], changes in Si:C ratios of sinking particles with depth in the ocean, and regional variations in the accumulation of $\mathrm{Si}$ and $\mathrm{C}$ on the seafloor [DeMaster, 1981; Treguer et al., 1995]. This concept has been reinforced by the hypothesis that, on a global basis, particulate organic carbon (POC) delivery to depth in the ocean is more effectively mediated by biogenic carbonate rather than opal 


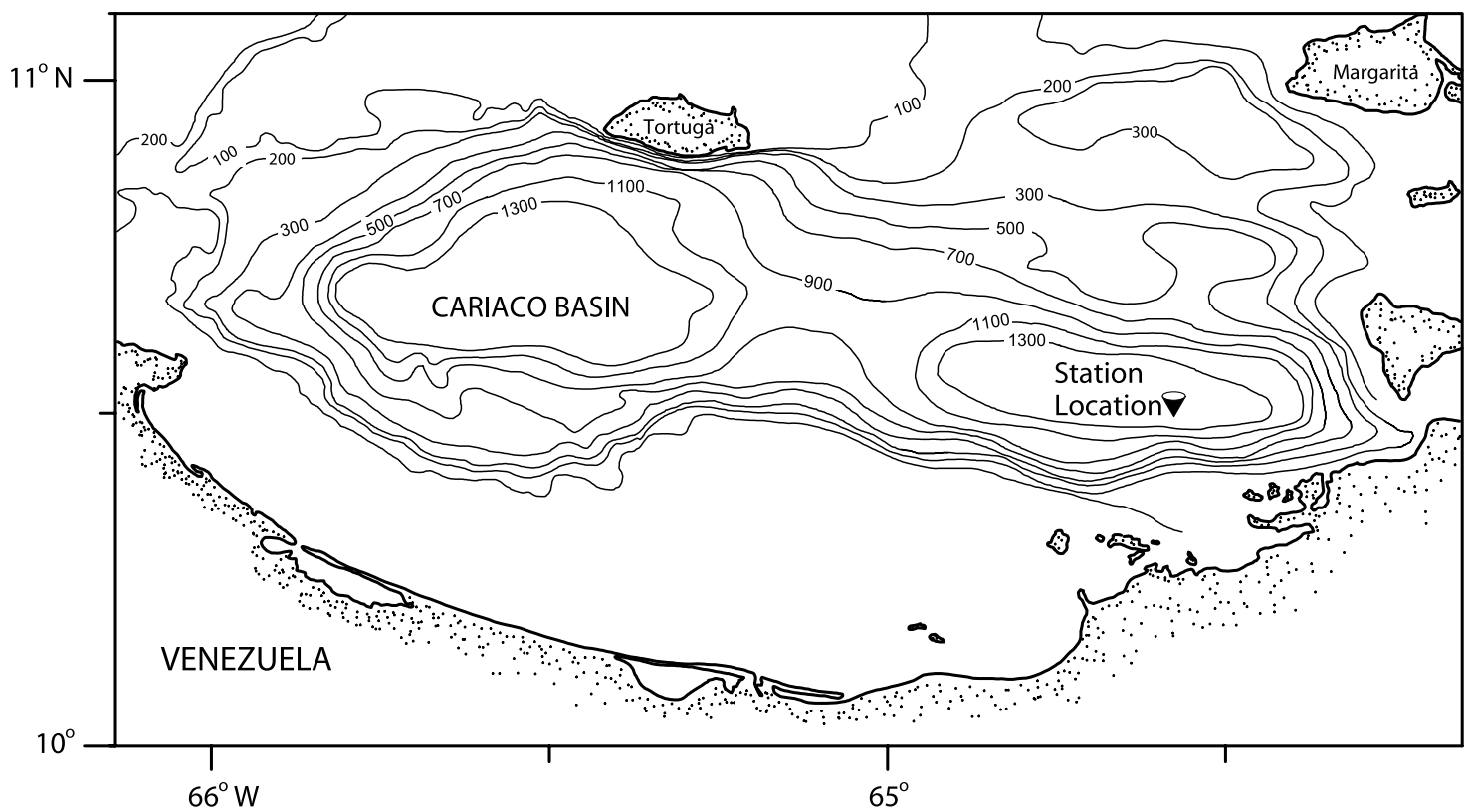

Figure 1. Bathymetric map of the Cariaco Basin showing the location of the time series study.

[Francois et al., 2002; Klaas and Archer, 2002]. However, Ragueneau et al. [2006] have argued that this POC:mineral association varies regionally, with opal actually having a higher carrying coefficient than carbonate in both the Atlantic and Indian Oceans. Similarly, Thunell et al. [2007] examined POC fluxes in several highly productive, coastal upwelling regions and found opal to be the most important "ballast" mineral in the Cariaco Basin.

[3] While nitrate $\left(\mathrm{NO}_{3}^{-}\right)$may be the "proximate" limiting nutrient for phytoplankton in most areas of the global ocean [Tyrrell, 1999], diatoms require $\mathrm{Si}$ to build their frustules. Thus, silicic acid $\left(\mathrm{Si}(\mathrm{OH})_{4}^{\bar{c}}\right)$ can be considered a limiting nutrient for this group of plankton [Brzezinski et al., 1990]. In regions of the ocean where nitrate is high, but chlorophyll concentrations and productivity are low (the so-called "high-nitrate, low-chlorophyll" regions), it is thought that iron availability may be a critical factor in limiting production [Martin, 1994; Coale et al., 1996; Behrenfeld et al. 2006]. However, there is evidence to suggest that silicate may also act as a limiting nutrient in some equatorial Pacific and Southern Ocean HNLC regions, with the silicate supply ultimately determining how much nitrate is utilized and the level of new production [Dugdale et al., 1995; Dugdale and Wilkerson, 1998]. The low silicate concentrations in these regions relative to nitrate may be due to a "silicate pump," with silicate being removed from the surface and delivered to depth before regeneration can occur, while nitrogen is recycled within the euphotic zone [Dugdale et al., 1995; Wilkerson and Dugdale, 1996].

[4] On the basis of culture studies, Brzezinski [1985] has shown that diatoms typically have mean $\mathrm{Si}: \mathrm{C}$ and $\mathrm{Si}: \mathrm{N}$ ratios of $\sim 0.13$ and $\sim 1.13$, respectively, when grown under nutrient-replete conditions. In regions where $\mathrm{Si}(\mathrm{OH})_{4}^{=}: \mathrm{NO}_{3}^{-}$ ratios are less than 1 , silicic acid is limiting and these uptake ratios will deviate from those that are typical of nutrient-rich conditions. Furthermore, on the basis of field observations in the equatorial Pacific Ocean [Price et al., 1994], the Southern Ocean [Takeda, 1998; Franck et al., 2000; Brzezinski et al., 2002], and coastal upwelling regimes [Hutchins and Bruland, 1998], as well as culturing studies [Timmermans et al., 2004], it has been demonstrated that Fe limitation causes diatoms to increase their uptake of $\mathrm{Si}(\mathrm{OH})_{4}=$ and decrease their consumption of $\mathrm{NO}_{3}^{-}$, resulting in depletion of $\mathrm{Si}(\mathrm{OH})_{4}^{=}$in surface waters. Thus, there may be a close association or coupling between Fe limitation and Si limitation [Nelson et al., 2001; Franck et al., 2000].

[5] In this paper we examine various aspects of the $\mathrm{Si}$ cycle in the Cariaco Basin, offshore Venezuela. We report on seasonal changes in upper water column $\mathrm{Si}(\mathrm{OH})_{4}^{\bar{z}}$ and $\mathrm{NO}_{3}^{-}$ concentrations, as well as temporal and depth-dependent changes in the $\mathrm{Si}: \mathrm{C}$ and $\mathrm{Si}: \mathrm{N}$ ratios of sinking particles collected from multiple depths in the basin over a 9-year period. Specifically, we examine (1) how nitrate and silicic acid availability varies in response to seasonal changes in hydrography, particularly the occurrence of upwelling, (2) whether $\mathrm{Si}(\mathrm{OH})_{4}$ is a limiting nutrient in this environment, (3) how the $\mathrm{Si}: \mathrm{C}$ and $\mathrm{Si}: \mathrm{N}$ ratios of sinking materials reflect seasonal changes in nutrient availability and phytoplankton composition, and (4) how these ratios vary with depth both in the water column and on the seafloor due to remineralization under both oxic and anoxic conditions. The Cariaco Basin is an ideal location for such a study because Si fluxes in this tropical setting are comparable to those seen at high latitudes.

\section{Materials and Methods}

\subsection{Study Area}

[6] The Cariaco Basin (Figure 1) is a 1400-m deep depression on the Venezuelan continental margin. Surface waters are freely exchanged between the basin and the open Caribbean above a sill depth of $\sim 100 \mathrm{~m}$. Two channels 
Table 1. Cariaco Basin Surface Sediment Core Data

\begin{tabular}{lccccc}
\hline \multicolumn{1}{c}{ Core } & Latitude & Longitude & Water Depth $(\mathrm{m})$ & Si:C & Si:N \\
\hline HG-MC 12-101 & $10^{\circ} 49.26^{\prime} \mathrm{N}$ & $64^{\circ} 42.86 \mathrm{~W}$ & 250 & 0.16 & 1.67 \\
HG-MC 4-A & $10^{\circ} 39.01^{\prime} \mathrm{N}$ & $64^{\circ} 36.64^{\prime} \mathrm{W}$ & 432 & 0.22 & 2.23 \\
PL07-103BC & $10^{\circ} 45.40^{\prime} \mathrm{N}$ & $65^{\circ} 20.20^{\prime} \mathrm{W}$ & 1133 & 0.22 & 2.15 \\
PL07-105BC & $10^{\circ} 43.47^{\prime} \mathrm{N}$ & $65^{\circ} 25.33^{\prime} \mathrm{W}$ & 1296 & 0.23 & 2.02 \\
PL07-64BC & $10^{\circ} 33.55^{\prime} \mathrm{N}$ & $64^{\circ} 47.31^{\prime} \mathrm{W}$ & 1375 & 0.24 & 2.10 \\
\hline
\end{tabular}

breach this sill, one in the northeast with a depth of $\sim 135 \mathrm{~m}$ (La Tortuga) and a narrower one in the northwest with a depth of $\sim 145 \mathrm{~m}$ (Centinela) [Lidz et al., 1969; Richards, 1975]. Because of restricted turnover of subsurface waters and high surface productivity, the decomposition of sinking organic matter leads to anoxic conditions in the basin below 250-300 m [Richards, 1975; Astor et al., 2003].

[7] The annual migration of the Inter-Tropical Convergence Zone (ITCZ) about the equator results in strong seasonal changes in upper ocean conditions in Cariaco Basin [Muller-Karger and Aparicio Castro, 1994]. The ITCZ is in its most southerly position during boreal winter and spring, at which time rainfall is minimized and strong easterly winds cause intense upwelling (3-5 $\mathrm{m} \mathrm{d}^{-1}$; Walsh et al. [1999]) and high primary productivity along the Venezuelan coast [Muller-Karger and Aparicio Castro, 1994]. Northward migration of the ITCZ occurs during the summer and early fall. This leads to an increase in rainfall and a decrease in trade wind strength in the Cariaco Basin region, with the latter causing upwelling and productivity to decrease. The relationship between seasonal changes in climatology and the production and flux of organic matter in the Cariaco Basin has been described by Thunell et al. [2000, 2007], Muller-Karger et al. [2001, 2004], and Goñi et al. [2003].

\subsection{Field Program and Sample Collection}

[8] An ongoing United States-Venezuelan time series study was initiated in Cariaco Basin in November 1995 [Muller-Karger et al., 2000, 2001]. The study includes monthly sampling cruises to a site in the eastern basin $\left(10.5^{\circ} \mathrm{N}, 64.67^{\circ} \mathrm{W} ; \sim 1400\right.$-m water depth; Figure 1) and the continuous measurement of particle fluxes at multiple depths at this location. The monthly cruises include routine hydrographic measurements (temperature, salinity, dissolved oxygen, and light transmission) of the entire water column. Additionally, primary production is measured at eight depths over the upper $100 \mathrm{~m}$, and water samples are collected for nutrient concentrations at discrete depths down to $\sim 1300 \mathrm{~m}$. A detailed description of the sampling program is provided by Muller-Karger et al. [2001].

[9] A single mooring containing five automated sediment traps is used to measure the vertical flux of particles at various depths in the Cariaco Basin water column. The two shallowest traps (Trap Z, $150 \mathrm{~m}$ and Trap A, $\sim 225 \mathrm{~m}$ ) are positioned above the oxic/anoxic interface $(\sim 275 \mathrm{~m})$, with the remaining traps at $410 \mathrm{~m}$ (Trap B), $810 \mathrm{~m}$ (Trap C), and $1200 \mathrm{~m}$ (Trap D). Each sediment trap contains 13 collecting cups, and samples are collected continuously for 2-week intervals. The mooring is recovered and redeployed every 6 months. For this study, we utilize samples collected from the four deepest sediment traps $(\mathrm{A}-\mathrm{D})$ for the 9 -year period from November 1996 through May 2005. Trap Z was added to the mooring in November 2003, and thus we have only a limited number of samples from this depth. In addition to the sediment trap samples, we analyzed surface sediment samples collected from multiple depths in the basin (Table 1).

\subsection{Analytical Methods}

[10] Water samples collected from 13 depths between the surface and 300-m water depth were used to determine the concentrations of $\mathrm{NO}_{3}^{-}$and $\mathrm{Si}(\mathrm{OH})_{4}^{=}$. For each of these nutrients, $1 \mathrm{~L}$ of water from each depth was filtered through a $0.8-\mu \mathrm{m}$ Nuclepore filter. The nitrate samples were frozen, while the water samples for $\mathrm{Si}(\mathrm{OH})_{4}=$ were refrigerated. The nutrient analyses were carried on a Technicon Analyzer II using the protocols recommended by Gordon et al. [1993]. The detection limits were $0.01 \mu \mathrm{M}$ for nitrate and $0.4 \mu \mathrm{M}$ for silicic acid.

[11] Primary production (mg $\mathrm{C} \mathrm{m}^{-3} \mathrm{~h}^{-1}$ ) was measured monthly on samples collected at eight depths $(1,7,15,25$, $35,55,75$, and $100 \mathrm{~m}$ ) using a modified Steeman Nielsen [1952] $\mathrm{NaH}^{14} \mathrm{CO}_{3}$ uptake assay. Data were integrated for the upper $100 \mathrm{~m}$ to produce daily primary productivity estimates $\left(\mathrm{g} \mathrm{C} \mathrm{m}^{-2} \mathrm{~d}^{-1}\right)$. The specifics of this sampling and procedure are provided by Muller-Karger et al. [2001].

[12] For the sediment trap samples, a buffered formalin solution was placed in each sample cup prior to deployment and served as a preservative for the particulate organic matter accumulating in the cups. Samples were stored in sealed containers and kept refrigerated after collection. Whole trap samples were split using a precision rotary splitter. A quarter of each sample was freeze-dried, ground, and used for a variety of geochemical analyses. Prior to freezing, these subsamples were examined under a microscope, and all obvious swimming organisms, not considered to be part of the particle flux, were removed before analysis.

[13] Particulate organic carbon (POC) and particulate nitrogen $(\mathrm{PN})$ concentrations were determined for both the sediment trap and surface sediment samples following the procedures outlined by Froelich [1980]. Samples were acidified $\left(1 \mathrm{M} \mathrm{H}_{3} \mathrm{PO}_{4}\right)$ to remove the particulate inorganic carbon (i.e., carbonates) and then combusted at $930^{\circ} \mathrm{C}$ in a Perkin Elmer 2400 elemental analyzer. POC and PN concentrations and molar ratios were calculated for all samples.

[14] Biogenic silicon (bSi) was determined on the sediment trap and surface sediment samples using the wet chemical leaching technique described by Mortlock and Froelich [1989]. Samples were initially treated with hydrochloric acid and hydrogen peroxide to remove carbonates and organics, respectively. Sodium carbonate was then used to dissolve the biogenic silica $\left(\mathrm{bSiO}_{2}\right)$, and the concentration of dissolved bSi was determined using a spectrophotometer. $\mathrm{Si}: \mathrm{C}$ and $\mathrm{Si}: \mathrm{N}$ molar ratios were then calculated for all samples.

\section{Results}

\subsection{Silicic Acid and Nitrate Concentrations in Cariaco Waters}

[15] Silicic acid concentrations in the upper $300 \mathrm{~m}$ of Cariaco Basin range from $50 \mu \mathrm{M}$ to less than $1.0 \mu \mathrm{M}$ and 
A.

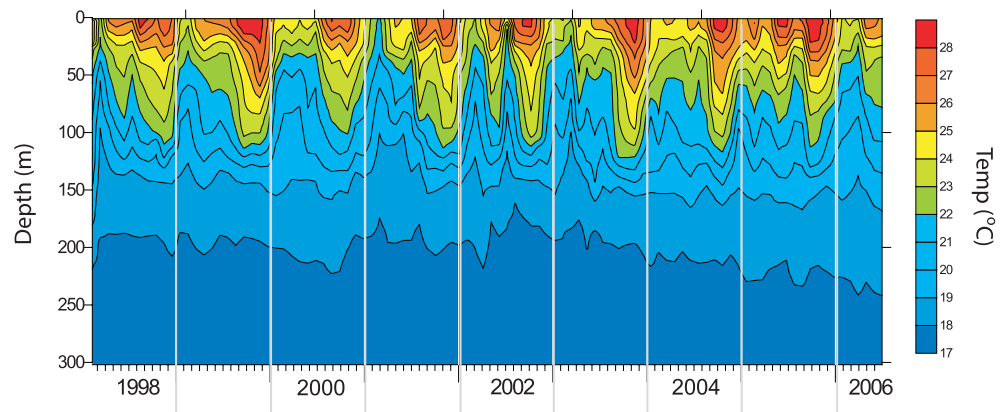

B.

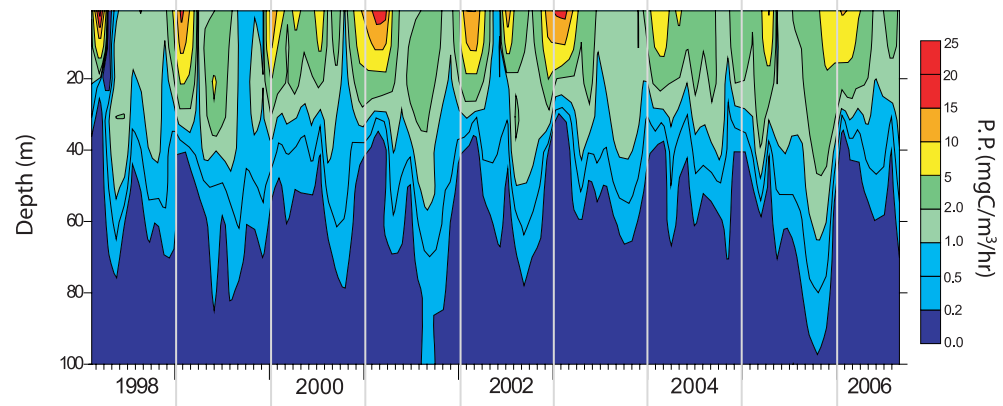

C.

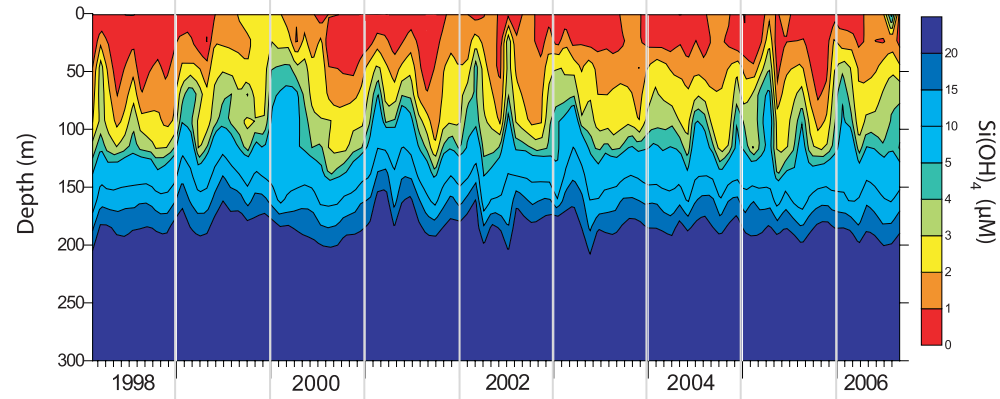

D.

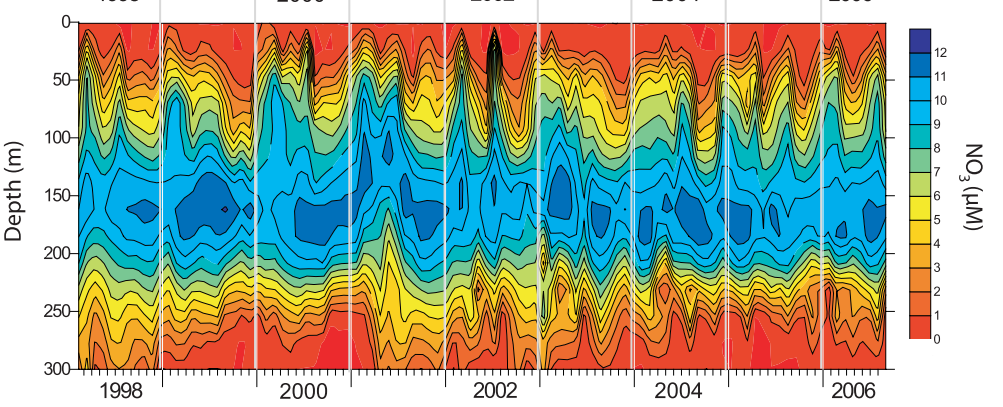

Figure 2. Seasonal variations in (a) temperature, (b) primary production, (c) silicic acid, and (d) nitrate in the upper $300 \mathrm{~m}$ of the water column at the Cariaco Basin time series study site for the period from 1998 to 2006 , with the exception of primary production which is to $100-\mathrm{m}$ depth.

are strongly depth-dependent (Figure 2). Surface waters are typically low in $\mathrm{Si}(\mathrm{OH})_{4}^{=}$, with values in the upper $50 \mathrm{~m}$ frequently less than $1.0 \mu \mathrm{M}$. At $100 \mathrm{~m}, \mathrm{Si}(\mathrm{OH})_{4}^{=}$concentrations usually reach $3-5 \mu \mathrm{M}$ and increase systematically with depth at a rate of $\sim 0.2 \mu \mathrm{M} \mathrm{m}^{-1}$ due to opal remineralization.

[16] Superimposed on these depth trends are seasonal changes in $\mathrm{Si}(\mathrm{OH})_{4}$ that are most apparent in the upper $100-150 \mathrm{~m}$ (Figures 2 and 3). During winter-spring, deeper waters enriched in $\mathrm{Si}(\mathrm{OH})_{4}^{=}$upwell to shallower depths; silicic acid concentrations of $2-4 \mu \mathrm{M}$ are found to depths of 25-50 m during this period. However, even during upwell- ing, surface waters commonly have $\mathrm{Si}(\mathrm{OH})_{4}^{\overline{7}}$ concentrations of $<1.0 \mu \mathrm{M}$. Conversely, during the summer and fall when surface waters are thermally stratified, $\mathrm{Si}(\mathrm{OH})_{4}^{\overline{7}}$ concentrations in the upper $300 \mathrm{~m}$ of the water column tend to be lower than during upwelling. For example, the $2.0 \mu \mathrm{M}$ $\mathrm{Si}(\mathrm{OH})_{4}^{=}$isopleth generally deepens to $\sim 75-100 \mathrm{~m}$ in the fall. These seasonal changes in silicic acid concentrations are also illustrated using mean vertical profiles for February and September (Figure 3). Figure 3 shows that $\mathrm{Si}(\mathrm{OH})_{4}^{=}$is higher at all depths during the winter relative to the late summer, except for the upper $25 \mathrm{~m}$ that are equally depleted in silicic acid. 


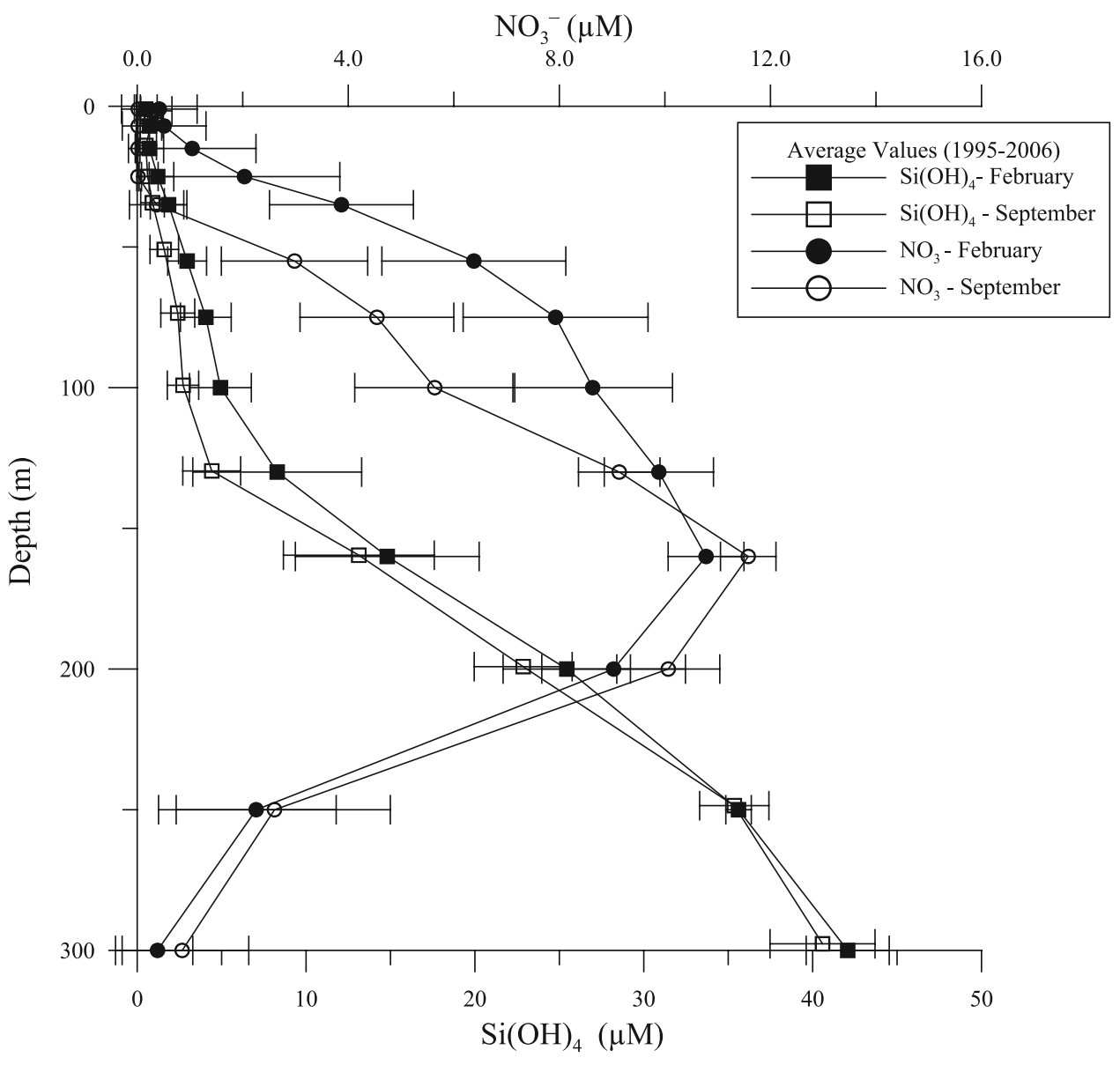

Figure 3. Mean depth profiles of nitrate (circles) and silicic acid (boxes) for February and September determined for the entire time series.

[17] Nitrate concentrations are low in the upper $50 \mathrm{~m}$ (generally $<2.0 \mu \mathrm{M}$ ), increase steadily with depth to maximum values $(>10 \mu \mathrm{M})$ between 100 and $200 \mathrm{~m}$, and then decrease below $200 \mathrm{~m}$ (Figure 2). This subsurface decrease in $\mathrm{NO}_{3}^{-}$is due to the nearly complete consumption of nitrate by denitrification at the oxic/anoxic interface [Thunell et al., 2004]. Like silicic acid, there are distinctive seasonal trends in nitrate concentrations in the upper $100 \mathrm{~m}$ of the water column. In the early part of each year, it is common to find nitrate values as high as $8.0-9.0 \mu \mathrm{M}$ between $50-$ and $100-\mathrm{m}$ depth, with values as high as $5 \mu \mathrm{M}$ extending upward to 25-m depth (Figure 3). By the latter part of the year, the $5-\mu \mathrm{M}$ isopleth usually deepens to $75-100-\mathrm{m}$ depth. The mean vertical profiles for February and September show that nitrate concentrations in the upper $25 \mathrm{~m}$ are $1.00 \pm 1.33 \mu \mathrm{M}$ during winter upwelling and are depleted $(0.02 \pm 0.03 \mu \mathrm{M})$ in summer (Figure 3).

$[18] \mathrm{Si}(\mathrm{OH})_{4}^{=}: \mathrm{NO}_{3}^{-}$ratios and $\mathrm{Si}^{*}$ (defined as $\mathrm{Si}(\mathrm{OH})_{4}$ $-\mathrm{NO}_{3}^{-}$by Brzezinski et al. [2002]) were also calculated (Figure 4). Significant seasonal variability in $\mathrm{Si}(\mathrm{OH})_{4}^{=}: \mathrm{NO}_{3}^{-}$ exists in the upper $100 \mathrm{~m}$ of the water column. During the winter, surface $\mathrm{Si}(\mathrm{OH})_{4}^{=}: \mathrm{NO}_{3}^{-}$ratios typically range from 2 to 4 and decrease to $<1$ by $25-50$-m depth. In some years (i.e., 2001), $\mathrm{Si}(\mathrm{OH})_{4}^{=}: \mathrm{NO}_{3}^{-}$ratios of less than 1 extend to the surface. Between approximately $75-150-\mathrm{m}$ depth, this ratio tends to be $<1$ throughout the year. Similarly, negative $\mathrm{Si}^{*}$ values indicate that waters between $\sim 50$ and $150 \mathrm{~m}$ are consistently depleted in $\mathrm{Si}(\mathrm{OH})_{4}^{=}$relative to $\mathrm{NO}_{3}^{-}$, with this depletion usually extending closer to the surface during winter and spring. During summer and fall, $\mathrm{Si}(\mathrm{OH})_{4}^{\bar{c}: \mathrm{NO}_{3}^{-}}$ ratios in the upper $50 \mathrm{~m}$ increase significantly, with $\mathrm{Si}^{*}$ values becoming positive. The uniformly high ratios below $200 \mathrm{~m}$ are a consequence of denitrification.

\section{2. $\mathrm{Si}: \mathrm{C}$ and Si:N Ratios of Sinking Particles and Surface Sediments}

[19] POC, PN, and Si fluxes were calculated for each sediment trap sample collected between November 1996 and May 2005 (except for trap Z where samples are only available for November 2003 to May 2005), and linear regression was used to determine the best fit values for the molar ratios of $\mathrm{Si}: \mathrm{C}$ and $\mathrm{Si}: \mathrm{N}$ at each of the five sediment trap depths (Figures 5 and 6). Significant correlations $(r>$ $0.8, p=0.001$ ) exist for both $\mathrm{Si}$ versus $\mathrm{C}$ and $\mathrm{Si}$ versus $\mathrm{N}$ at each sediment trap depth. For both $\mathrm{Si}: \mathrm{C}$ and $\mathrm{Si}: \mathrm{N}$, there is an increase in the ratios between $150 \mathrm{~m}$ and $410 \mathrm{~m}$ (Figures 5 and 6); Si:C increases from $0.17 \pm 0.01$ to $0.24 \pm 0.01$, and Si:N increases from $1.14 \pm 0.10$ to $2.17 \pm 0.10$ over this depth range. Below $410 \mathrm{~m}, \mathrm{Si}: \mathrm{C}$ and $\mathrm{Si}: \mathrm{N}$ values are fairly uniform. Similar depth-dependent changes are seen in the 

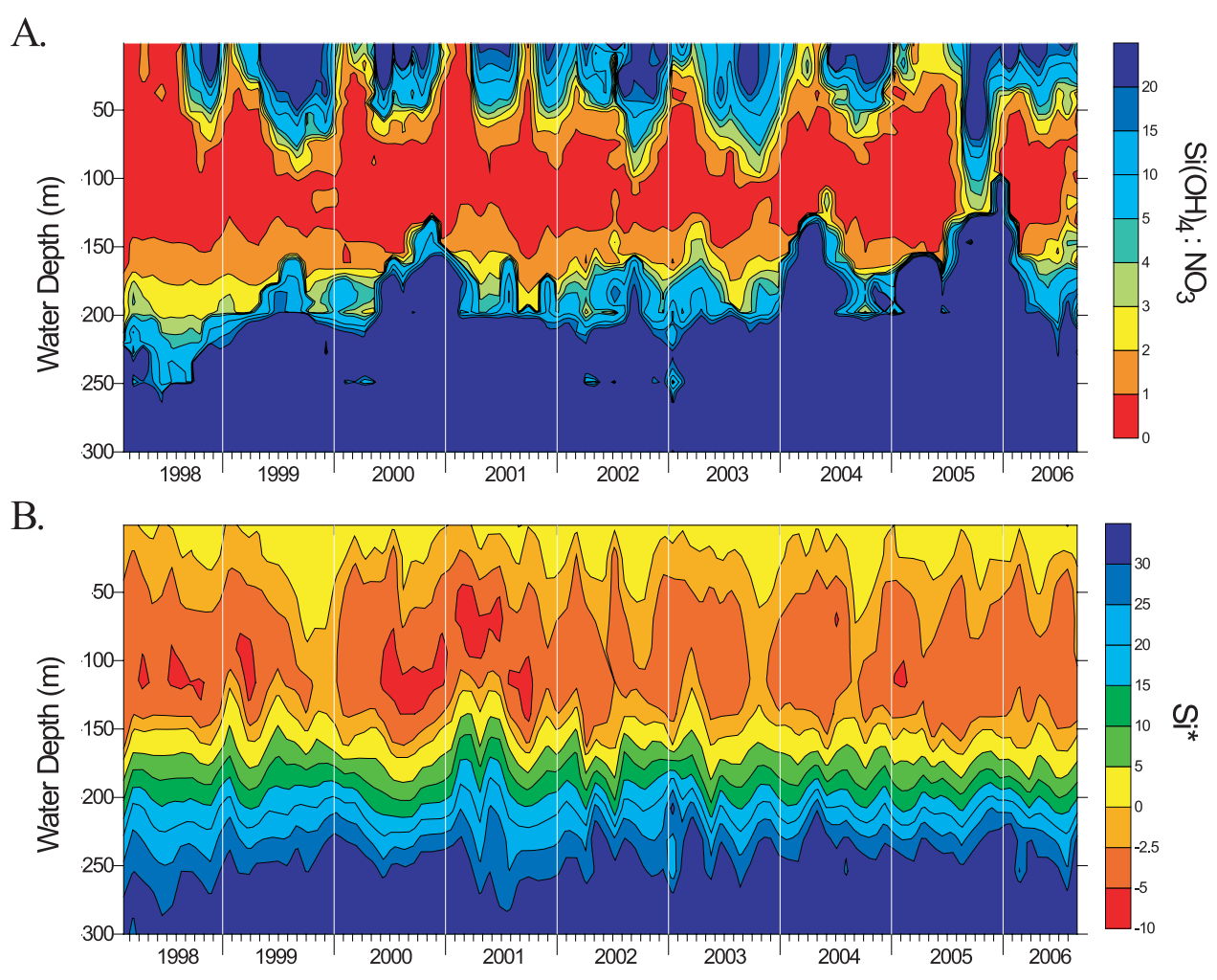

Figure 4. Seasonal variations in (a) the $\mathrm{Si}(\mathrm{OH})_{4}: \mathrm{NO}_{3}$ ratio and (b) $\mathrm{Si}^{*}$ in the upper $300 \mathrm{~m}$ of the water column at the Cariaco Basin time series study site for the period from 1998 to 2006.

Si:C and Si:N ratios of surface sediments from the basin (Figures 5 and 6). Between 250 and 430-m depth, surface sediment $\mathrm{Si}: \mathrm{C}$ and $\mathrm{Si}: \mathrm{N}$ ratios increase from 0.16 to 0.22 and from 1.67 to 2.23 , respectively. Below $430 \mathrm{~m}$, there is little change in the surface sediment ratios. The Si:C and $\mathrm{Si}: \mathrm{N}$ ratios of 0.17 and 1.14 , respectively, determined for the shallowest trap are very similar to the $\mathrm{Si}$ : $\mathrm{C}$ ratio of 1.1 and $\mathrm{Si}: \mathrm{N}$ ratio of 0.13 found in diatom cultures grown under nutrient-replete conditions [Brzezinski, 1985].

[20] Temporal changes in the $\mathrm{Si}: \mathrm{C}$ and $\mathrm{Si}: \mathrm{N}$ ratios for each trap depth for the 9-year time series are plotted in order to evaluate seasonal to interannual variability in the composition of sinking particulates in Cariaco Basin (Figure 7). The time-dependent changes in $\mathrm{Si}: \mathrm{C}$ and $\mathrm{Si}: \mathrm{N}$ are strongly covariant and marked by distinctive seasonal cycles that are consistent with depth (Figures 7). Si:C values range from $\sim 0.1$ to 0.4 , while most $\mathrm{Si}: \mathrm{N}$ values fall between 1.0 and 3.0. For both ratios, the highest values occur during the winter and then decline during the early spring. In some years, this is followed by a secondary increase in both ratios in late spring to early summer, with minimum values of $\mathrm{Si}: \mathrm{C}$ and $\mathrm{Si}$ N occurring during the remainder of the summer and fall. There does not appear to be any systematic long-term change in either Si:C or Si:N during the last decade.

\section{Discussion}

\subsection{Seasonal Changes in $\mathrm{Si}(\mathrm{OH})_{4}^{\bar{y}}$ and $\mathrm{NO}_{3}^{-}$ Availability}

[21] Regional climate exerts a strong influence over hydrographic conditions and, in turn, the upper water column nutrient chemistry in Cariaco Basin [Scranton et al., 2006]. Increased trade wind velocities during winterspring result in upwelling of nutrient-rich waters and high levels of primary production along this region of the Venezuelan margin [Muller-Karger and Aparicio Castro, 1994; Muller-Karger et al., 2001]. This upwelling is visible in the rapid shoaling of isotherms that begins in December to January of each year and higher rates of primary production (Figures 2a and $2 \mathrm{~b}$ ). Conversely, relaxation of the winds during the summer and fall diminishes upwelling and results in lower primary production. The observed changes in $\mathrm{Si}(\mathrm{OH})_{4}^{=}$and $\mathrm{NO}_{3}^{-}$concentrations in the upper $150 \mathrm{~m}$ of the water column (Figures $2 \mathrm{c}$ and $2 \mathrm{~d}$ ) are a manifestation of these seasonal hydrographic changes, along with nutrient utilization during photosynthesis.

[22] Upwelling in early winter brings silicate and nitraterich waters into the photic zone (Figures $2 \mathrm{c}$ and $2 \mathrm{~d}$ ). At $100-\mathrm{m}$ depth, both silicic acid and nitrate increase to $10 \mu \mathrm{M}$ at the onset of upwelling. At the same time, it is common to have $\mathrm{Si}(\mathrm{OH})_{4}^{=}$and $\mathrm{NO}_{3}^{-}$values as high as $\sim 4 \mu \mathrm{M}$ and $\sim 7 \mu \mathrm{M}$, respectively, at depths as shallow as $25 \mathrm{~m}$. During upwelling, the silicate and nitrate gradients in the upper $100 \mathrm{~m}$ of the water column reach their maximum. This injection of nutrients immediately stimulates primary production, with virtually all of this production occurring in the upper $50 \mathrm{~m}$ of the water column (Figure $2 \mathrm{~b}$ ). However, even during upwelling, surface waters tend to be depleted $(<1 \mu \mathrm{M})$ in both $\mathrm{Si}(\mathrm{OH})_{4}^{=}$and $\mathrm{NO}_{3}^{-}$as a result of rapid utilization. Only in late 1999 to early 2000 do we observe silicate values as high as $2-3 \mu \mathrm{M}$ at the surface. These values are 

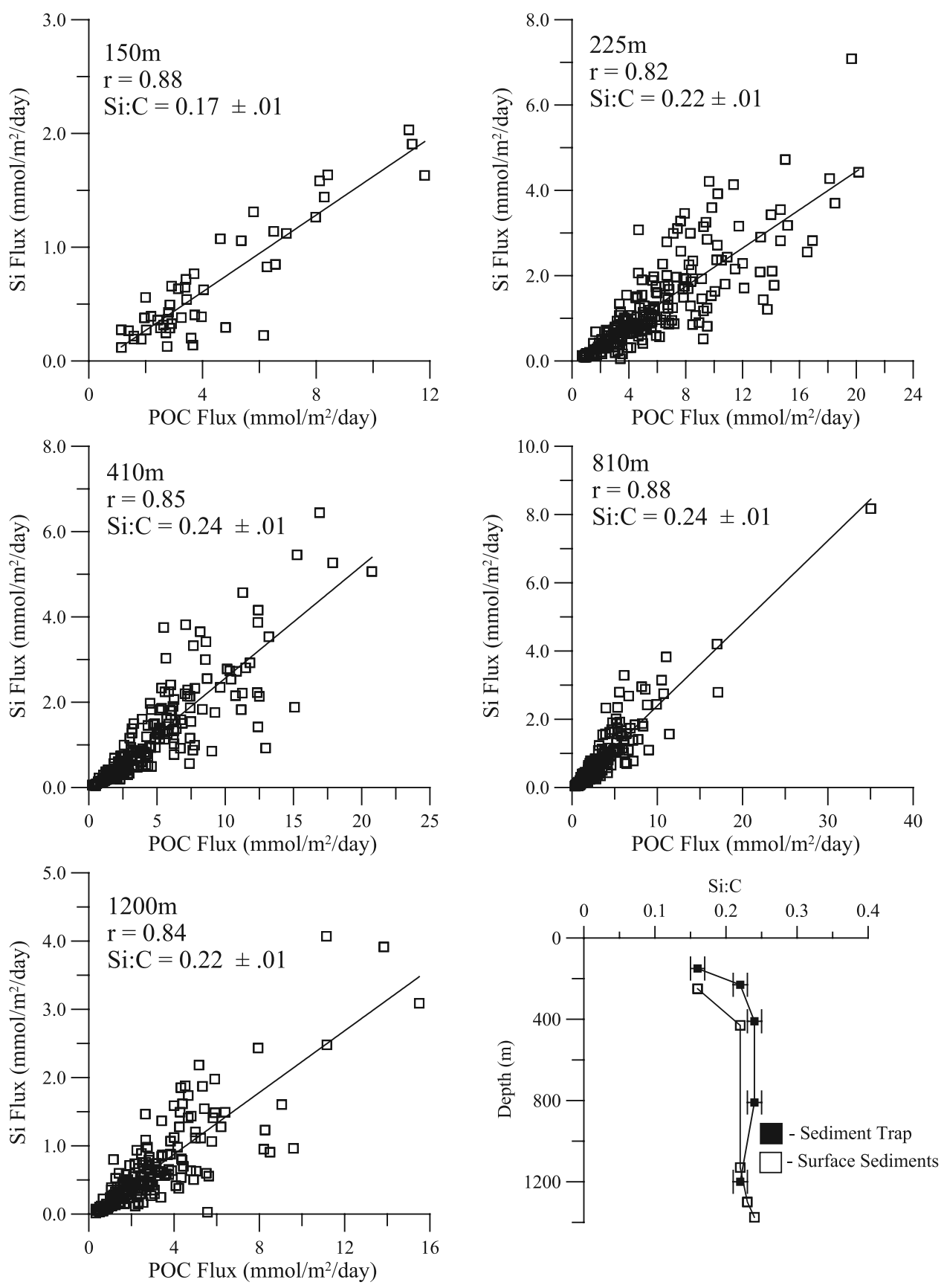

Figure 5. Si flux versus POC flux for the five Cariaco Basin sediment trap depths. All fluxes are in $\mathrm{mmol} \mathrm{m} \mathrm{m}^{-2} \mathrm{~d}^{-1}$. The best fit linear regression line, correlation coefficient $(r)$, and average $\mathrm{Si}$ : $\mathrm{C}$ ratio are shown for each depth. Changes in the average sediment trap $\mathrm{Si}: \mathrm{C}$ (solid boxes) and surface sediment $\mathrm{Si}: \mathrm{C}$ (open boxes) as a function of depth are shown in the bottom right portion of the figure.

most likely due to the anomalously high precipitation and runoff that occurred in coastal Venezuela at this time [Wieczorek et al., 2001]. As will be discussed in section 4.4 , the generally low silicate values in surface waters during upwelling is an indication that silicate may act as a limiting nutrient for diatom growth in Cariaco Basin.

[23] With the relaxation of upwelling in the summer, the surface layer becomes thermally stratified and temperatures as warm as $22^{\circ} \mathrm{C}$ extend to $100-\mathrm{m}$ depth during the fall
(Figure 2a). The silicic acid and nitrate gradients over this depth interval are at a minimum during the nonupwelling period. Surface water (upper $25 \mathrm{~m}$ ) concentrations of both silicic acid $(0.78 \pm 0.71 \mu \mathrm{M})$ and nitrate $(0.02 \pm 0.03 \mu \mathrm{M})$ are very depleted during the nonupwelling season (Figures $2 \mathrm{c}$, $2 \mathrm{~d}$, and 3 ).

[24] $\mathrm{Si}(\mathrm{OH})_{4}^{=}: \mathrm{NO}_{3}^{-}$ratios and $\mathrm{Si}^{*}$ were calculated for the upper $300 \mathrm{~m}$ of the water column in order to determine if silicate availability may limit diatom growth in Cariaco 

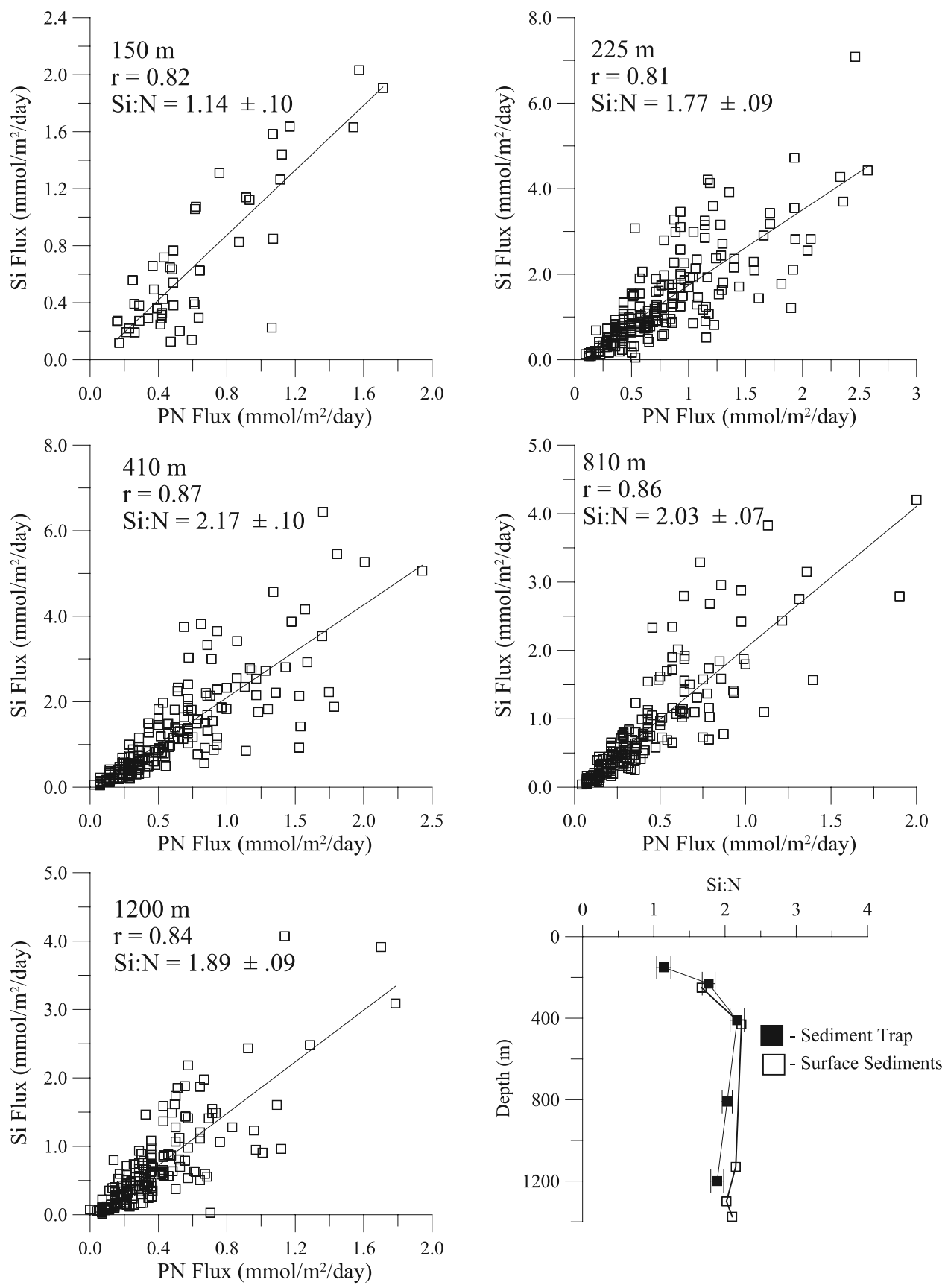

Figure 6. Si flux versus PN flux for the five Cariaco Basin sediment trap depths. All fluxes are in mmol $\mathrm{m}^{-2} \mathrm{~d}^{-1}$. The best fit linear regression line, correlation coefficient $(r)$, and average Si:N ratio are shown for each depth. Changes in the average sediment trap Si:N (solid boxes) and surface sediment Si:N (open boxes) as a function of depth are shown in the bottom right portion of the figure.

Basin (Figure 4). For example, if we assume that diatoms normally have a $\mathrm{Si}(\mathrm{OH})_{4}^{=}: \mathrm{NO}_{3}^{-}$utilization ratio of roughly 1 [Brzezinski, 1985], then a ratio of less than 1 would indicate that diatoms are silicate limited. Negative values of $\mathrm{Si}^{*}$ further reflect silicate limiting conditions. We are particularly interested in the values for these two parameters in the upper 50-100 $\mathrm{m}$ of the water column since this is where most of the nutrient utilization and primary production occurs in Cariaco Basin (Figure 2b). Both $\mathrm{Si}(\mathrm{OH})_{4}^{=}: \mathrm{NO}_{3}^{-}$ ratios and $\mathrm{Si}^{*}$ clearly indicate that silicate concentrations may restrict the production of Si-dependent plankton, at least seasonally, in Cariaco Basin. In most years, the winter, and often the spring, are marked by $\mathrm{Si}(\mathrm{OH})_{4}^{=}: \mathrm{NO}_{3}^{-}$ratios of less than 1 extending upward to depths shallower than $50 \mathrm{~m}$ (Figure $4 \mathrm{a})$. Furthermore, $\mathrm{Si}^{*}$ values of less than 1 often extend to the surface during the first half of the year (Figure 4b). Thus, silicate limitation in Cariaco Basin is most severe during upwelling, when nutrient utilization and 

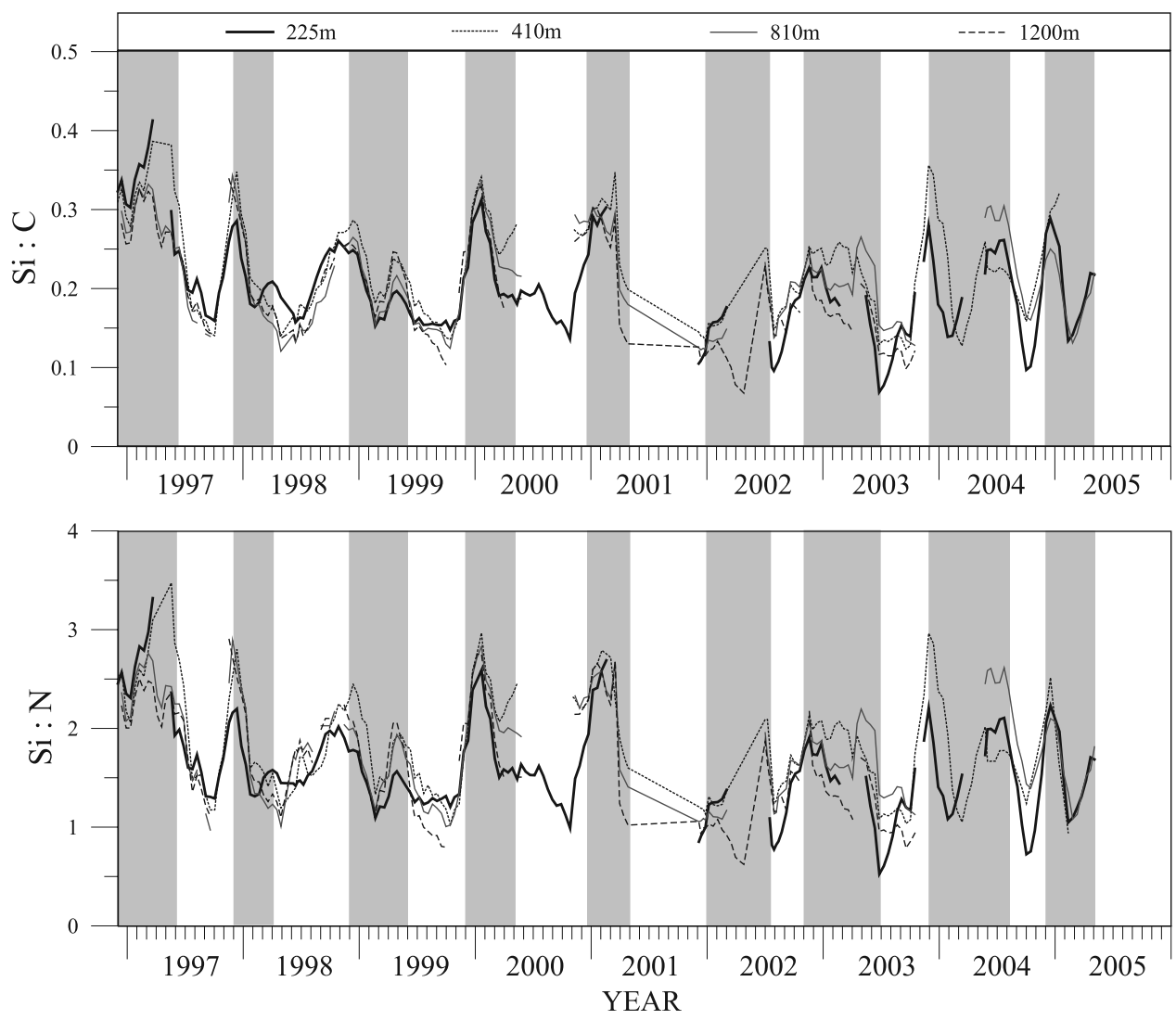

Figure 7. Seasonal changes in the (top) $\mathrm{Si}: \mathrm{C}$ and (bottom) Si:N ratios of sinking particles collected in sediment traps A, B, C, and D for the period 1997 to 2005.

primary production are greatest. On the basis of an examination of the sediment trap samples, we know that diatom fluxes are highest during the upwelling season and that they dominate the total siliceous plankton production (O. Romero and R. Thunell, unpublished data, 2008). Thus, high utilization during the winter upwelling causes silicate concentrations in surface waters to be low. Conversely, during the summer and fall when upwelling is reduced and primary production decreases, we find that $\mathrm{Si}(\mathrm{OH})_{4}^{=}: \mathrm{NO}_{3}^{-}$ratios in the upper $50 \mathrm{~m}$ of the water column are frequently greater than 5 (Figure 4a), implying that nitrate rather than silicate is acting to limit production during this time of year. These higher ratios reflect reduced utilization of silicate and virtually complete consumption of nitrate during this half of the year.

\subsection{Biogenic Si Fluxes in Cariaco Basin}

[25] On the basis of a compilation of available data, Nelson et al. [1995] estimated that the mean daily opal production rate in the global ocean is on the order 1.6$2.2 \mathrm{mmol} \mathrm{Si} \mathrm{m}{ }^{-2} \mathrm{~d}^{-1}$. Regionally, silica production rates vary significantly; oligotrophic midocean gyre regions commonly have production rates as low as $0.1-0.2 \mathrm{mmol}$ Si m $\mathrm{m}^{-2} \mathrm{~d}^{-1}$, while it is not uncommon for coastal upwelling

Table 2. Sediment Trap Mean Daily Si Flux Estimates

\begin{tabular}{lccc}
\hline \multicolumn{1}{c}{ Location } & Trap Depth $(\mathrm{m})$ & Si Flux $\left(\mathrm{mmol} \mathrm{m} \mathrm{d}^{-1}\right)$ & Reference \\
\hline Cariaco Basin & 225 & $1.30 \pm 1.03$ & This study \\
Cariaco Basin & 410 & $1.05 \pm 0.88$ & This study \\
Cariaco Basin & 810 & $0.74 \pm 0.59$ & This study \\
Cariaco Basin & 1200 & $0.61 \pm 0.55$ & This study \\
Bransfield Strait Southern Ocean & 494 & 2.49 & Wefer et al. $[1988]$ \\
Maud Rise Southern Ocean & 360 & 1.09 & Wefer and Fischer $[1991]$ \\
Polar Front Southern Ocean & 614 & 1.09 & Ragueneau et al. $[2000]$ \\
Equatorial Pacific Upwelling & 1883 & 0.90 & Dymond and Collier $[1988]$ \\
California Current & 1500 & 0.57 & Dymond and Lyle [1994] \\
Arabian Sea Upwelling & 914 & 1.01 & Ragueneau et al. [2000] \\
Panama Basin & 890 & 0.54 & Honjo [1982] \\
\hline
\end{tabular}



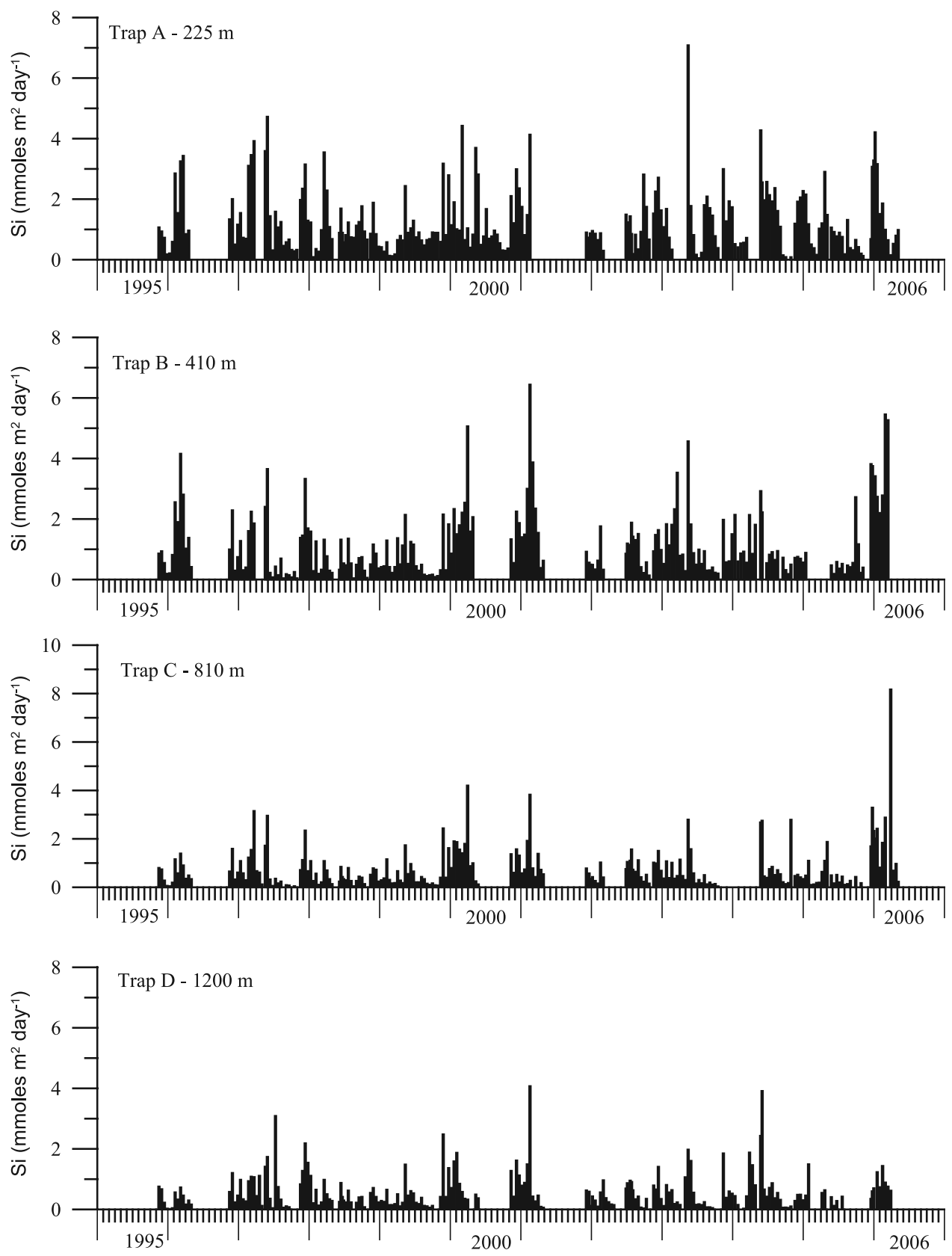

Figure 8. Time series of Si fluxes for sediment traps A, B, C, and D for the period 1996 to 2005. All fluxes are in $\mathrm{mmol} \mathrm{m} \mathrm{m}^{-2} \mathrm{~d}^{-1}$.

regions to have production rates exceeding $100 \mathrm{mmol} \mathrm{Si}$ $\mathrm{m}^{-2} \mathrm{~d}^{-1}$ [Nelson et al., 1995; Ragueneau et al., 2000]. Unfortunately, no direct measurements of opal production are available for Cariaco Basin. However, biogenic Si fluxes should serve as an indirect measure of opal production even though remineralization has occurred. Since we have very limited data for the 150-m sediment trap, we use the data at $230 \mathrm{~m}$ as a proxy for surface opal production in Cariaco Basin (Table 2). At this depth, Si fluxes vary by nearly 2 orders of magnitude from less than 0.1 mmoles $\mathrm{m}^{-2} \mathrm{~d}^{-1}$ to almost 7.0 mmoles $\mathrm{m}^{-2} \mathrm{~d}^{-1}$ (Figure 8). Most years, the maximum Si fluxes are in the range of 3-4 mmoles $\mathrm{m}^{-2} \mathrm{~d}^{-1}$, with the average $230-\mathrm{m}$ flux for the entire 9-year time series being $1.30 \pm 1.03$ mmoles $\mathrm{m}^{-2} \mathrm{~d}^{-1}$ (or an average annual $\mathrm{Si}$ flux of 0.47 moles $\mathrm{m}^{-2} \mathrm{a}^{-1}$ ) (Table 2 and Figure 8). These flux values are comparable to those previously reported for highly productive locations (Table 2) in the Southern Ocean [Wefer et al., 1988; Pondaven et al., 2000; Ragueneau et al., 2000; Wefer and Fischer, 1991], as well upwelling zones in the equatorial Pacific [Dymond and Collier, 1988], the California Margin California Margin [Dymond and Lyle, 1982], the Arabian Sea [Ragueneau et al., 2000], and the Panama Basin [Honjo, 1982]. On the basis of this similarity with Si fluxes from regions known to have very high opal 
production rates, we infer that Cariaco Basin is also a region of high opal production.

\subsection{Depth-Dependent Changes in the $\mathrm{Si}: \mathrm{C}$ and $\mathrm{Si}: \mathrm{N}$ Composition of Sinking Particles and Surface Sediments}

[26] The elemental composition of both sinking and suspended particles is likely to change with depth because of differential remineralization rates for biogenic elements (Honjo and Manganini [1993], Nelson et al. [1996], Schneider et al. [2004], Ragueneau et al. [2002], among others). For example, Honjo and Manganini [1993] found PON to be the least resistant to degradation, followed by $\mathrm{POC}$ and $\mathrm{bSi}$. Because of this differential preservation, more $\mathrm{bSi}$ is exported from surface waters relative to PON and POC, a phenomenon referred to as the "silicate pump" [Dugdale et al. 1995]. On the basis of a compilation of available elemental data, Ragueneau et al. [2002] determined that there is a systematic increase in $\mathrm{Si}: \mathrm{C}$ with depth in the ocean and that this is controlled not only by different remineralization rates but also by a variety of other processes including herbivore grazing on diatoms within the mesopelagic zone.

[27] Thunell et al. [2000, 2007] previously demonstrated that there is significant loss of particles to remineralization and dissolution within both the oxic and anoxic zones of the Cariaco water column. They found that on average the POC flux decreased by $\sim 55 \%$ between the $225-$ and $1200-\mathrm{m}$ sediment traps. In this study, the mean Si flux decreases from $1.30 \pm 1.03$ mmoles $\mathrm{m}^{-2} \mathrm{~d}^{-1}$ at $225 \mathrm{~m}$ to $0.61 \pm$ 0.55 mmoles $\mathrm{m}^{-2} \mathrm{~d}^{-1}$ at $1200 \mathrm{~m}$, representing an average loss of over $50 \%$ (Table 2 and Figure 8). This loss may significantly affect the $\mathrm{Si}: \mathrm{C}$ and $\mathrm{Si}: \mathrm{N}$ ratios of the sinking particles in Cariaco Basin and thus their relative distributions in the dissolved phase.

[28] The $\mathrm{Si}: \mathrm{C}$ and $\mathrm{Si}: \mathrm{N}$ ratios of the sediment trap samples increase with depth, with most of this change occurring between trap Z $(150 \mathrm{~m})$ and trap B $(410 \mathrm{~m})$ (Figures 5 and 6). $\mathrm{Si}: \mathrm{C}$ increases by $30 \%$ between 150 and $225 \mathrm{~m}(0.17$ to 0.22 ) and by an additional $18 \%$ between $225-$ and $410-\mathrm{m}$ depth (0.26). Below $410 \mathrm{~m}$, there is no further increase in $\mathrm{Si} \mathrm{C}$ and, in fact, the ratio decreases slightly to 0.23 at $1200 \mathrm{~m}$. The Si:N ratios follow a very similar depth similar pattern (Figure 6). There is a $55 \%$ increase in the ratio between 150 and $225 \mathrm{~m}$, and a further increase of just over $20 \%$ by $410 \mathrm{~m}$. Like $\mathrm{Si}: \mathrm{C}$, the $\mathrm{Si}: \mathrm{N}$ ratio exhibits a small decrease from 2.17 at $410 \mathrm{~m}$ to 1.89 at $1200 \mathrm{~m}$. The increases in both ratios within the upper several hundred meters of the water column can be attributed to the fact that organic matter is remineralized more rapidly than biogenic silica under aerobic conditions [Ragueneau et al., 2002], with $\mathrm{N}$ being most rapidly regenerated. The lack of a further increase in either ratio below $410 \mathrm{~m}$ suggests that there is no selective removal of elements via remineralization in the anoxic portion of the water column, despite the fact that there is significant loss of sinking particles within this zone. A decrease in the rate of regeneration of organic matter within the anoxic portion would cause the $\mathrm{Si}: \mathrm{C}$ and $\mathrm{Si}: \mathrm{N}$ ratios to stabilize or even decrease. Thus, the impact of remineralization processes on $\mathrm{Si}: \mathrm{C}$ ratios in the upper several hundred meters of the water column in Cariaco Basin is similar to those in most regions of the open ocean [Ragueneau et al., 2002]. However, this trend does not hold within the anoxic portion of the basin where $\mathrm{C}$ and $\mathrm{N}$ are no longer preferentially removed relative to $\mathrm{Si}$ because of changes in remineralization processes (i.e., sulfate reduction is the primary pathway for organic matter degradation in the anoxic portion of the basin [Thunell et al., 2000]).

[29] The depth-dependent changes we observe in the $\mathrm{Si}: \mathrm{C}$ and $\mathrm{Si}: \mathrm{N}$ ratios of sinking particles are mirrored in the elemental ratios preserved in surface sediments (Table 1 and Figures 5 and 6). The $\mathrm{Si}: \mathrm{C}$ and $\mathrm{Si}: \mathrm{N}$ ratios of surface sediment samples increase by $\sim 25 \%$ between 252 and $432 \mathrm{~m}$, and then remain fairly uniform below this depth. This pattern, as well as the absolute values, is quite similar to sinking particles from comparable depths. For example, the mean Si:N ratio for the $225-\mathrm{m}$ trap is $1.77 \pm 0.9$, while surface sediment from $252 \mathrm{~m}$ has a Si:N ratio of 1.67. This ratio increases to $2.17 \pm 0.10$ for the 410 -m trap and to 2.23 for the 432-m sediment sample. This strong similarity suggests that the surface sediments were recently deposited and have not undergone significant postdepositional remineralization.

\subsection{Seasonal Changes in the $\mathrm{Si}: \mathrm{C}$ and $\mathrm{Si}: \mathrm{N}$ Composition of Sinking Particles}

[30] The depth-dependent change in $\mathrm{Si}: \mathrm{C}$ and $\mathrm{Si}: \mathrm{N}$ ratios cannot explain the distinctive and consistent seasonal variations in these ratios seen at all trap depths (Figure 7). Rather, the observed temporal changes in Si:C and $\mathrm{Si}: \mathrm{N}$ ratios of sinking particles produced in surface waters primarily are a function of two other factors: (1) nutrient availability and utilization by diatoms and (2) the relative contribution of diatoms to the total plankton community. As previously mentioned, diatoms grown in culture under nutrient-replete conditions have mean $\mathrm{Si}: \mathrm{C}$ and $\mathrm{Si}: \mathrm{N}$ ratios of $0.13 \pm 0.04$ and $1.12 \pm 0.33$, respectively [Brzezinski, 1985], although in the ocean there is significant regional variability in these ratios due to these two factors [Ragueneau et al., 2006]. For example, in the oligotrophic waters near Bermuda, low surface silicic acid concentrations result in a low contribution of diatoms to primary production and consequently Si:C ratios of only 0.02 [Nelson and Brzezinski, 1997]. Conversely, in the Southern Ocean, the $\mathrm{Si}: \mathrm{C}$ ratio of newly produced particles averages $\sim 0.25$ because of significantly higher production rates of opal relative to organic carbon in this region [Ragueneau et al., 2002]. Similarly, under Fe-limited conditions Si:N ratios may be several times higher than the expected ratio of $\sim 1$ [Takeda, 1998; Hutchins and Bruland, 1998].

[31] Clearly, not all of the primary production in Cariaco Basin is from diatoms. Although diatoms overwhelmingly dominate the siliceous plankton in the basin (O. Romero and R. Thunell, unpublished data, 2008), there are nonsiliceous plankton groups which contribute to the total particle flux. Since our elemental ratios are based on the analysis of bulk sediment samples, the inclusion of these nonsiliceous groups will cause the $\mathrm{Si}: \mathrm{N}$ and $\mathrm{Si}: \mathrm{C}$ ratios to be lower than 
that of a sample composed predominantly of diatoms [Brzezinski et al., 2003]. Also, the magnitude of this effect will vary seasonally as the proportion of diatoms to nondiatom phytoplankton changes. On the basis of the preliminary work of O. Romero and R. Thunell (unpublished data, 2008), diatoms contribute most significantly to the total plankton during the winter-spring upwelling period and then decrease in relative importance during the summer and fall. Furthermore, the trap ratios will be shifted higher than the original uptake values because of water column regeneration. Thus, we cannot use these ratios as absolute indicators of $\mathrm{Si}: \mathrm{N}$ and $\mathrm{Si}: \mathrm{C}$ uptake by diatoms in Cariaco Basin. Rather, the ratios provide an integrated measure of both changes in diatom nutrient utilization and the contribution of diatoms to the total plankton.

[32] For the four traps (A, B, C, and D) where we have multiple years of data, a repeatable seasonal pattern is present in the $\mathrm{Si}: \mathrm{C}$ and $\mathrm{Si}: \mathrm{N}$ ratios that is consistent at all depths (Figure 7). Both ratios are highest during the early part of the year when upwelling is most intense and diatoms are most abundant. During summer and fall, both Si:C and Si:N decrease to their lowest values. At least initially, the high values of these ratios during upwelling periods seem counterintuitive. Given that upwelling injects $\mathrm{NO}_{3}^{-}$and $\mathrm{Si}(\mathrm{OH})_{4}^{=}$-rich waters into the euphotic zone (Figure 2), it is reasonable to expect that the ratios during this time of year would be more in line with those associated with abundant nutrients [Brzezinski, 1985]. Specifically, we would expect $\mathrm{Si}: \mathrm{N}$ and $\mathrm{Si}: \mathrm{C}$ ratios to be closer to 1 and 0.1 during upwelling periods, rather than the observed values of 2-3 and 0.3 , respectively (Figure 7). Such high values for these ratios can be attributed to the operation of a "silicate pump" in which particulate silica is more efficiently exported from surface waters relative to $\mathrm{N}$ and $\mathrm{C}$ [Dugdale et al., 1995; Brzezinski et al., 2003]. As a result of this preferential removal of silica, silicic acid concentrations become limiting and produce the low surface water values of $\mathrm{Si}(\mathrm{OH})_{4}^{=}: \mathrm{NO}_{3}^{-}$and $\mathrm{Si}^{*}$ we observe during upwelling (Figure 4).

[33] During the nonupwelling period (summer and fall) we observe $\mathrm{Si}: \mathrm{N}$ and $\mathrm{Si}: \mathrm{C}$ ratios that are more typical of nutrient replete conditions. However, the diatom contribution to the total particle flux during this time of year is significantly reduced (O. Romero and R. Thunell, unpublished data, 2008), and thus the lower ratios may be largely attributed to a greater contribution of nonsiliceous plankton, rather than to a change in nutrient availability.

[34] Numerous studies have shown that under Fe limitation, $\mathrm{NO}_{3}^{-}$utilization is suppressed and the resultant $\mathrm{Si}: \mathrm{N}$ ratio of diatoms increases [Hutchins and Bruland, 1998; Takeda, 1998; Franck et al., 2000; Brzezinski et al., 2003]. Of particular relevance to our study is the work of Hutchins and Bruland [1998] carried out along the central California margin, a coastal upwelling regime very similar to that of Cariaco Basin. Despite its proximity to land, surface waters in this region have very low dissolved Fe concentrations. Hutchins and Bruland [1998] found that diatom Si:N uptake ratios were high $(2-3)$ despite high nutrient concentrations associated with upwelling and attributed this to Fe limitation. The enhanced utilization of silicic acid associated with
Fe-deficiency causes surface waters to become more depleted in $\mathrm{Si}(\mathrm{OH})_{4}=$ compared to $\mathrm{NO}_{3}$, driving the system toward silica limitation. While we observe low $\mathrm{Si}(\mathrm{OH})_{4}^{=}$ $: \mathrm{NO}_{3}^{-}$ratios and negative $\mathrm{Si}^{*}$ values in the upper $50 \mathrm{~m}$ of Cariaco Basin each year during upwelling (Figure 4), we do not have any dissolved Fe data to determine directly if $\mathrm{Fe}$ limitation is occurring. At this point, we can only speculate that Fe limitation may be contributing to the high $\mathrm{Si}: \mathrm{N}$ ratios that occur during the upwelling season in Cariaco Basin.

\section{Conclusions}

[35] The Cariaco Basin is a site of high opal production, and the cycling of $\mathrm{Si}$ in the basin is controlled largely by the pronounced seasonal changes in upper ocean conditions. Although upwelling during the winter and spring injects nutrients into the photic zone that stimulate production, surface waters are depleted in silicic acid relative to nitrate. Sinking particles produced during the winter/spring upwelling season tend to have high $\mathrm{Si}: \mathrm{C}$ and $\mathrm{Si}: \mathrm{N}$ ratios, indicating a more efficient export of $\mathrm{Si}$ relative to organic matter during this time of year. While high $\mathrm{Si}: \mathrm{N}$ ratios are a sign of Fe limitation, we have no direct evidence to indicate that this is occurring in Cariaco Basin. The $\mathrm{Si}: \mathrm{C}$ and $\mathrm{Si}: \mathrm{N}$ ratios of sinking particles are considerable lower during the nonupwelling period. This most likely represents a significant increase in the production of nonsiliceous plankton during this time of year.

[36] Si:C and Si:N ratios of both sinking particles and surface sediments increase with depth within the upper several hundred meters because of selective remineralization, but then remain constant below $400 \mathrm{~m}$ within the anoxic portion of the basin. This depth-dependent pattern reflects the fact that organic matter $(\mathrm{C}$ and $\mathrm{N})$ is degraded more rapidly than opal in the oxic portion of the water column and that this difference is minimized within the deeper, anoxic waters and sediments.

[37] Acknowledgments. We thank E. Tappa for maintaining the sediment trap time series in Cariaco Basin and for analytical support. We also acknowledge the crew of the RV Hermano Gines for their dedicated support of the time series cruises. This research was supported by NSF grant 0326313 .

\section{References}

Astor, Y., F. Muller-Karger, and M. I. Scranton (2003), Seasonal and interannual variation in the hydrography of the Cariaco Basin: Implications for basin ventilation, Cont. Shelf Res., 23, -, doi:10.1016/S02784343(02)00130-9.

Behrenfeld, M., K. Worthington, R. Sherrell, F. Chavez, P. Strutton, M. McPhaden, and D. Shea (2006), Controls on tropical Pacific Ocean productivity revealed through nutrient stress diagnostics, Nature, 442, 1025-1028, doi:10.1038/nature05083.

Brzezinski, M. (1985), The Si:C:N ratio of marine diatoms: Interspecific variability and the effect of some environmental variables, J. Phycol., 21, $347-357$.

Brzezinski, M., R. Olson, and S. Chisholm (1990), Silicon availability and cell-cycle progression in marine diatoms, Mar. Ecol. Progr. Ser., 67, 8396.

Brzezinski, M., C. Pride, V. Franck, D. Sigman, J. Sarmiento, K. Matsumoto, N. Gruber, G. Rau, and K. Coale (2002), A switch from Si $(\mathrm{OH})_{4}$ to $\mathrm{NO}_{3}^{-}$ depletion in the glacial Southern Ocean, Geophys. Res. Lett., 29(12), 1564, doi:10.1029/2001GL014349.

Brzezinski, M., M. Dickson, D. Nelson, and R. Sambrotto (2003), Ratios of $\mathrm{Si}, \mathrm{C}$ and $\mathrm{N}$ uptake by microplankton in the Southern Ocean, Deep Sea Res., 50, 619-633, doi:10.1016/S0967-0645(02)00587-8. 
Buesseler, K. (1998), The decoupling of production and particulate export in the surface ocean, Global Biogeochem. Cycles, 12, 297-310, doi:10.1029/97GB03366.

Coale, K., et al. (1996), A massive phytoplankton bloom induced by an ecosystem-scale iron fertilization experiment in the equatorial Pacific Ocean, Nature, 383, 495-501, doi:10.1038/383495a0.

DeMaster, D. (1981), The supply and accumulation of silica in the marine environment, Geochim. Cosmochim. Acta, 45, 1715-1732, doi:10.1016 0016-7037(81)90006-5.

Dugdale, R., and F. Wilkerson (1998), Silicate regulation of new production in the equatorial Pacific upwelling, Nature, 391, 270-273, doi:10.1038/ 34630

Dugdale, R., F. Wilkerson, and H. Minas (1995), The role of the silicate pump in driving new production, Deep Sea Res., 42, 697-719, doi:10.1016/0967-0637(95)00015-X.

Dymond, J., and R. Collier (1988), Biogenic particle fluxes in the equatorial Pacific: Evidence for both high and low productivity during the 1982 1983 El Niño, Global Biogeochem. Cycles, 2, 129-137.

Dymond, J., and M. Lyle (1982), Flux comparisons between sediments and sediment traps in the eastern tropical Pacific: Implications for atmospheric $\mathrm{CO}_{2}$ variations during the Pleistocene, Limnol. Oceanogr., 30 , 699-712.

Dymond, J., and M. Lyle (1994), Particle fluxes in the ocean and implications for the sources and preservation of ocean sediments, in Studies in Geophysics: Material Fluxes on the Surface of the Earth, edited by Natl. Res. Counc., pp. 125-142, Natl. Acad. Press, Washington, D. C.

Franck, V., M. Brzezinski, K. Coale, and D. Nelson (2000), Iron and silicic acid concentrations regulate Si uptake north and south of the Polar Frontal Zone in the Pacific sector of the Southern Ocean, Deep Sea Res., 47 , 3315-3338, doi:10.1016/S0967-0645(00)00070-9.

Francois, R., S. Honjo, R. Krishfield, and S. Manganini (2002), Factors controlling the flux of organic carbon to the bathypelagic zone of the ocean, Global Biogeochem. Cycles, 16(4), 1087, doi:10.1029/ 2001GB001722.

Froelich, P. N. (1980), Analysis of organic carbon in marine sediments, Limnol. Oceanogr., 25, 565-572.

Goñi, M., H. Aceves, R. Thunell, E. Tappa, and D. Black (2003), Biogenic fluxes in the Cariaco Basin: A combined study of sinking particulates and underlying sediments, Deep Sea Res., 50, 781-807, doi:10.1016/S09670637(03)00060-8.

Gordon, L. I., J. C. Jennings Jr., A. A. Ross, and J. M. Krest (1993), A suggested protocol for continuous flow automated analysis of seawater nutrients, in WOCE Operation Manual, WHP Off. Rep. 90-1, pp. 1-52, World Meteorol. Org., Geneva.

Honjo, S. (1982), Seasonality and interaction of biogenic and lithogenic particle flux at the Panama Basin, Science, 218, 883-884.

Honjo, S., and S. Manganini (1993), Annual biogenic particle fluxes to the interior of the North Atlantic Ocean; studies at $34^{\circ} \mathrm{N} 21^{\circ} \mathrm{W}$ and $48^{\circ} \mathrm{N} 21^{\circ} \mathrm{W}$, Deep Sea Res., 40, 587-607, doi:10.1016/0967-0645(93)90034-K.

Hutchins, D., and K. Bruland (1998), Iron-limited diatom growth and Si:N uptake ratios in a coastal upwelling regime, Nature, 393, 561-564, doi:10.1038/31203.

Klaas, C., and D. Archer (2002), Association of sinking organic matter with various types of mineral ballast in the deep sea: Implications for the rain ratio, Global Biogeochem. Cycles, 16(4), 1116, doi:10.1029/ $2001 \mathrm{~GB} 001765$

Lidz, L., W. B. Charm, M. M. Ball, and S. Valdes (1969), Marine basins off the coast of Venezuela, Bull. Mar. Sci., 19, 1-17.

Martin, J. (1994), Testing the iron hypothesis in the equatorial Pacific Ocean, Nature, 371, 123-129, doi:10.1038/371123a0.

Mortlock, R., and P. Froelich (1989), A simple method for the rapid determination of biogenic opal in pelagic marine sediments, Deep Sea Res., 36, 1415-1426, doi:10.1016/0198-0149(89)90092-7.

Muller-Karger, F. E., and R. Aparicio Castro (1994), Mesoscale processes affecting phytoplankton abundance in the southern Caribbean Sea, Cont Shelf Res., 14, 199-221, doi:10.1016/0278-4343(94)90013-2.

Muller-Karger, F., et al. (2000), Sediment record linked to surface processes in the Cariaco Basin, Eos Trans. AGU, 81, 529-535.

Muller-Karger, F. E., et al. (2001), Annual cycle of primary production in the Cariaco Basin: Response to upwelling and implications for vertical export, J. Geophys. Res., 106, 4527-4542, doi:10.1029/1999JC000291.

Muller-Karger, F., R. Varela, R. Thunell, Y. Astor, H. Zhang, and C. Hu (2004), Processes of coastal upwelling and carbon flux in Cariaco Basin, Deep Sea Res., 51, 927-943.

Nelson, D., and M. Brzezinski (1997), Diatom growth and productivity in an oligotrophic mid-ocean gyre: A 3-year record from the Sargasso Sea near Bermuda, Limnol. Oceanogr., 42, 473-486.
Nelson, D., P. Treguer, M. Brzezinski, A. Leynaert, and B. Queguiner (1995), Production and dissolution of biogenic silica in the ocean: Revised global estimates, comparison with regional data and relationship to biogenic sedimentation, Global Biogeochem. Cycles, 9, 359-372, doi:10.1029/95GB01070.

Nelson, D., D. DeMaster, R. Dunbar, and W. And Smith (1996), Cycling of organic carbon and biogenic silica in the Southern Ocean: Estimates of water column and sedimentary fluxes on the Ross Sea continental shelf, J. Geophys. Res., 101, 18,519-18,532, doi:10.1029/96JC01573.

Nelson, D., M. Brzezinski, D. Sigmon, and V. And Franck (2001), A seasonal progression of Si limitation in the Pacific sector of the Southern Ocean, Deep Sea Res., 48, 3973-3995, doi:10.1016/S0967. 0645(01)00076-5.

Pondaven, P., O. Ragueneau, P. Tréguer, A. Hauvespre, L. Dezileau, and J. L. Reyss (2000), Resolving the opal paradox in the Southern Ocean, Nature, 405, 168-172, doi:10.1038/35012046.

Price, N., B. Ahner, and F. Morel (1994), The equatorial Pacific Ocean: Grazer controlled phytoplankton populations in an iron-limited ecosystem, Limnol. Oceanogr., 39, 520-539.

Ragueneau, O., et al. (2000), A review of the silica cycle in the modern ocean: Recent progress and missing gaps in the application of biogenic opal as a paleoproductivity proxy, Global Planet. Change, 26, 317-365, doi:10.1016/S0921-8181(00)00052-7.

Ragueneau, O., N. Dittert, P. Pondaven, P. Treguer, and L. Corrin (2002), $\mathrm{Si} / \mathrm{C}$ decoupling in the world ocean: Is the Southern Ocean different? Deep Sea Res., 49, 3127-3154, doi:10.1016/S0967-0645(02)00075-9.

Ragueneau, O., S. Schultes, K. Bidle, P. Claquin, and B. Moriceau (2006), $\mathrm{Si}$ and $\mathrm{C}$ interactions in the world ocean: Importance of ecological processes and implications for the role of diatoms in the biological pump, Global Biogeochem. Cycles, 20, GB4S02, doi:10.1029/2006GB002688.

Richards, F. A. (1975), The Cariaco Basin (Trench), Annu. Rev. Oceanogr. Mar. Biol., 13, 11-67.

Sarmiento, J., and N. Gruber (2006), Ocean Biogeochemical Dynamics, 503 pp., Princeton Univ. Press, N. J.

Sarmiento, J., N. Gruber, M. Brzezinski, and J. And Dunne (2004), Highlatitude controls of thermocline nutrients and low latitude biological productivity, Nature, 427, 56-60, doi:10.1038/nature02127.

Schneider, B., A. Engel, and R. Schlitzer (2004), Effects of depth- and CO 2 -dependent $\mathrm{C}: \mathrm{N}$ ratios of particulate organic matter (POM) on the marine carbon cycle, Global Biogeochem. Cycles, 18, GB2015, doi:10.1029/2003GB002184

Scranton, M. I., M. McIntyre, G. T. Taylor, F. Muller-Karger, K. Fanning, and Y. Astor (2006), Temporal variability in the nutrient chemistry of the Cariaco Basin, in Past and Present Marine Water Column Anoxia, edited by L. N. Neretin, NATO Sci. Ser. IV, vol. 64, pp. 139-160, Springer, New York.

Steeman Nielsen, E. (1952), The use of radioactive carbon $\left({ }^{14} \mathrm{C}\right)$ for measuring organic production in the sea, J. Cons. Cons. Int. Explor. Mer., 18, $117-140$.

Takeda, S. (1998), Influence of iron availability on nutrient consumption ratio of diatoms in oceanic waters, Nature, 393, 774-777, doi:10.1038/ 31674.

Thunell, R., R. Varela, M. Llano, J. Collister, F. Muller-Karger, and R. Bohrer (2000), Organic carbon flux in an anoxic water column: Sediment trap results from the Cariaco Basin, Limnol. Oceanogr., 45, 300-308.

Thunell, R., D. Sigman, F. Muller-Karger, Y. Astor, and R. Varela (2004), The nitrogen isotope dynamics of the Cariaco Basin, Venezuela, Global Biogeochem. Cycles, 18, GB3001, doi:10.1029/2003GB002185.

Thunell, R., C. Benitez-Nelson, R. Varela, Y. Astor, and F. Muller-Karger (2007), Particulate organic carbon fluxes along upwelling-dominated continental margins: Rates and mechanisms, Global Biogeochem. Cycles, 21, GB1022, doi:10.1029/2006GB002793.

Timmermans, K., B. van der Wagt, and H. de Baar (2004), Growth rates, half-saturation constants, and silicate, nitrate and phosphate depletion in relation to iron availability of four large, open-ocean diatoms from the Southern Ocean, Limnol. Oceanogr., 49, 2141-2151.

Treguer, P., D. Nelson, A. Van Bennekom, D. DeMaster, A. Leynaert, and B. Queguiner (1995), The silica balance in the world ocean: A reestimate, Science, 268, 375-379, doi:10.1126/science.268.5209.375

Tyrrell, T. (1999), The relative influences if nitrogen and phosphorus on oceanic primary production, Nature, 400, 525-531, doi:10.1038/22941. Walsh, J. J., et al. (1999), simulation of carbon-nitrogen cycling during spring upwelling in the Cariaco Basin, J. Geophys. Res., 104, 78077825, doi:10.1029/1998JC900120.

Wefer, G., and G. Fischer (1991), Annual primary production and export flux in the Southern Ocean from sediment trap data, Mar. Chem., 35, $597-613$. 
Wefer, G., G. Fischer, D. Futterer, and R. Gersonde (1988), Seasonal particle flux in the Bransfield Strait, Antarctica, Deep Sea Res., 35, $891-$ 898, doi:10.1016/0198-0149(88)90066-0.

Wieczorek, G., M. Larsen, L. Eaton, B. Morgan, and J. Blair (2001), Debris-flow and flooding hazards associated with the December 1999 storm in coastal Venezuela and strategies for mitigation, U. S. Geol. Surv Open File Rep. 01-144, 40 pp.
Wilkerson, F., and R. Dugdale (1996), Silicate versus nitrate limitation in the equatorial Pacific estimated from satellite-derived sea-surface temperatures, Adv. Space Res., 18, 81-89, doi:10.1016/0273-1177(95)00951-5.

C. Benitez-Nelson and R. Thunell, Department of Geological Sciences and Marine Science Program, University of South Carolina, Columbia, SC 29208, USA. (thunell@geol.sc.edu)

K. Fanning, L. Lorenzoni, and F. Muller-Karger, College of Marine Science, University of South Florida, St. Petersburg, FL 33701, USA.

M. Scranton, Marine Sciences Research Center, Stony Brook University, Stony Brook, NY 11794, USA.

Y. Astor and R. Varela, Fundacion La Salle de Ciencias Naturales, Estacion de Investigaciones Marinas de Margarita, Isla de Margarita, Porlamar 6301, Venezuela. 